\title{
UK Copyright and the Limits of UK Music Sampling
}

Julie Ewald, Dr Paul G. Oliver

Perth College, University of the Highlands \& Islands, UK

\begin{abstract}
Music sampling is the act of taking a piece of an existing sound recording (the sample) and then using it in a new track. Sampling an original work without permission can infringe its copyright and therefore lead to lawsuits. There has still not been settled a single lawsuit regarding music sampling in the UK courts. It is therefore unclear to what extent music sampling can be used without infringing copyright. The overall aim of this paper is to establish the limits of music sampling and thereby determine whether music sampling could be used without infringing copyright laws.
\end{abstract}

The literature review establishes the history and development of music sampling and determines the applicable laws. It also determines that there are two main exceptions to copyright; fair dealings and "de minimis," which will be considered in the analysis.

The methods used to analyse these two exceptions to copyright are the critical legal doctrine and the black letter analysis, which means that the analysis is based upon the statutes and case law. Due to the lack of UK case law, it is necessary to focus primarily upon case law from the US. Additionally, a survey was conducted to gather quantitative data regarding the use and perception of music sampling and its legality.

In the analysis the two exceptions to copyright are considered. It is found that the fair dealings exception cannot be applied upon music sampling, while the "de minimis" exception can be applied, if the sample is not substantially similar to the original work. This meant that a sample could only be considered as "de minimis" in some very limited circumstances. Finally, it is showed how musicians believe that this current legal situation regarding music sampling can have a limiting effect upon their creativity.

Overall, it is determined throughout this paper that the current copyright laws do not reflect the technological changes that has enabled musicians to unfold their creativity through "new" methods such as music sampling. It is therefore necessary that both the current law and their interpretation in courts are more relaxed in order not to damage the creative expression.

Keywords: Copyright Law, Music Sampling, Music Industries, UK 


\subsection{Introduction}

"Thou shalt not steal" were the words from the American Judge Kevin Thomas Duffy, as he in 1991 stated his decision in the Grand Upright Music Ltd v. Warner Brothers Records Inc. case. His honour here decided that a Biz Markie's use of a 10 second sample from Raymond Gilbert O’Sullivan's track “Alone again (Naturally)" was an infringement of copyright and even possibly also a criminal offence. This case was one of the first cases regarding music sampling and copyright to ever be settled by a court, and several cases have since been brought for the courts in the US. However, no similar cases have been brought for the UK courts, which leave UK artists in an uncertain position ${ }^{1}$.

Sampling can be defined as a copy or reuse of a larger or smaller piece of an already existing recording/track (Passman 2012: 344). Sampling therefore implies that it is based upon someone else's copyright, which means that sampling can be an infringement of both the author's, the performing artist's and the record label's rights. There is currently a lot of confusion regarding the legality of music sampling, due to very little statutory guidance and the general lack of court rulings. Despite the fact that sampling affects several copyright issues, sampling is still a very unknown subject area in legal literature and especially within case law - At this current moment no sampling cases have been decided by the UK courts. ${ }^{2}$ The UK legal situation regarding sampling must therefore be considered undetermined and unclear.

Even though sampling has been addressed more within US legal literature and even though there are a large number of court cases regarding sampling in the US. This legal situation is still somewhat unclear here as well, due to the uneven interpretation of the copyright laws among the American courts.

The sampling issues are a part of an important general debate regarding copyright and whether copyright should uphold these unnecessary obstacles for sampling artists' creativity.

This paper aims to clarify and analyse the current copyright rules and their application in relation to music sampling in the UK, so it will be possible to establish to what extent music sampling can be used in accordance with the applicable laws. The thesis will additionally discuss the impact of the limitations

\footnotetext{
${ }^{1}$ Any searches in case law databases, such as Westlaw or Bailii (British and Irish Legal Information Institute), show that there have not been any court decisions regarding music sampling.

2 ibid
} 
to music sampling upon creativity and thereby also discuss whether there is a need for a broader interpretation of the 'de minimis' exception in relation to music sampling.

This thesis will consider whether a less rigid interpretation and application of the copyright laws could result in an increased creativity, which overall, could be beneficial for the music industry as a whole.

The thesis will try to answer these questions through a review and analyse the relevant copyright laws as well as analyse the copyright infringement evaluation in relation to sampling. In connection to this, relevant case law will be examined. Finally, the thesis will try to consider the future prospects of the relationship between copyright law and sampling.

\subsection{Literature Review}

\subsection{Introduction}

Before dealing with the questions regarding the extent of the copyright protection and the impact on creativity, which the thesis aims to answer, it is necessary to first establish the concept of music sampling and copyright, as well as determine the applicable laws. The literature review will do that in the following.

\subsection{Defining Music Sampling}

Music sampling is the process of digitally copying a piece of a recording; this could be anything from a guitar sound, drum sound or voice (Poe 2006: 59). This new sample is then inserted and used in a new recording (Passman 2012: 344). Sampling music is an example of a collage art form, which has existed since the beginning of the $20^{\text {th }}$ century. This collage art form was used in pictorial art, however in the 1940s this technique was expanded into the musical art of 'sounds-collages'. This art form, which was given the name "the technique musique concrete", was developed in Europe by Pierre Schaeffer. He experimented by cutting magnetic tapes with recordings and reassembling them in a different order, with changed tempo, looping etc. (Hodgkinson 1986).

\subsection{The Historical Background for Music Sampling}

It has been argued that music sampling has its roots in Jamaican culture around 1950's, where selectors (DJs) would talk/sing over a record. American Hip Hop producers then subsequently adopted this style 
(Self 2001: 350). Within popular music these techniques were also being used. One of the earliest examples of a music sample is The Flying Saucer by Bill Buchanan and Dickie Goodman from 1956. This track used samples from 10 different top chart hits. Despite this the Guinness World Record is recognising John Kongos' "He’s Gonna Step on You Again” from 1971 as the example of the earliest music sampling on a record.

\subsection{Music Sampling Today}

In the 1970 s the first digital samplers were created, however these digital samplers did not get proper entry on the market until the 1980s. At this point their costs were reduced and quality improved, so it became easier for the average artist to get hold of one. The easier access to digital samplers meant that

sampling became popular at this time, especially in electronic and rap music. Today, sampling in it self has also become a creative art (Greenfield 2004: 93) and it is widely known within other genres of music. Sampling is not merely used for the purposes of copying well-known original work, but it is also used to manipulate and transform other samplings and original works (Théberge 2004: 149) (Chanan 1995: 162-3). Due to the wider use of sampling, databases, such as WhoSampled.com (2016) have been created to make it easier for consumers (and artists) to figure out who has sampled whom. The page allows anyone to submit information of samples. This is helpful for artists, who want to protect their work, as it is impossible for the artist himself to listen to all music to ensure that their copyrights are not being infringed. In a way this new website makes listeners/music consumers "guarddogs" for the artists and their copyright. Currently the database has more than 335,804 songs, 117,293 artists and 195,147 samples (Who 2015).

Generally, there seems to be a change in attitude towards sampling, as it becomes more and more widespread. Today licensing agreements are commonly created to avoid the conflict between samplers and copyright holders (Lubin 2014: 11). Despite this, illegal sampling does still exist and samplers often infringe the copyright law.

\subsection{Applicable Copyrights Laws}

Music sampling implies that an artist is using or exploiting someone else's intellectual property to create a new work (Wixen 2009: 158). Using music sampling can infringe primarily two copyrights; the copyright in the sound recording (owned by the record company and/or the artist) and the copyright of the underlying musical composition (owned by the publishing company and/or songwriter) (Digital 
Music News 2015). The music sample can include everything from a single bass line of a pre-existing recording or it can use the entire pre-existing recording with additional instrumentation and/or lyrics added (Poe 2006: 60).

Music sampling is derivative and also often parasitic towards the existing record too. It is meant to be derivative, because it is derived from an original work (Poe 2006: 60), and parasitic, because a sample can have a negative impact on the original work's market or it will at least base its own success upon the former success of the existing record (Théberge 2004: 149). Nevertheless, it has been seen in several cases that the sampling work can have a positive impact as it can create a new revival for the original work, and possibly expand its previous and current market. This has for example been seen with Girl Talk's more than 300 samples, since the sales of the original works generally all went up in the year after the release of the sampling work compared to the year before (Schuster 2013). Regardless of whether the impact is positive or negative, the use of the sample can infringe the copyright of the original recording.

Copyright is the legal right of the creator/originator of a work. To own the copyright to a work means to have the right to control how the material is being used and not used (UK Copyright Service 2015). So if an artist uses a sample without permission, then they will generally be infringing or breaching copyright. There are certain exceptions to this rule. In some situations, despite the lack of permission to use the sample, the use of it does not necessarily mean that the copyright has been infringed (Théberge 2004: 149). This occurs in situations where the sample falls under either a 'fair use' and the 'de minimis' exception. These exceptions will be examined in more detail later.

Generally, the court cases on sampling were few and far between (Self 2001: 358), due to the fact that the parties in these cases were often more interested in getting cases settled outside the courts, as this could reduce possible costs and to limit the courts determining power on their specific situation (Greenfield 2004: 93). This in itself has created a legal uncertainty and lack of clarity about what the legal boundaries are regarding music sampling. Despite a recent growth in court cases regarding music sampling, there is still a need for a clarification of the current legal position for music sampling. 
Copyright laws in the UK, as we know them today originated from a concept of common law called the Statute of Anne 1709/1710 ${ }^{3}$. This statute extended the royal protection to book authors (Self 2001:356, Samuels 2000: Ch. 1). Previously it was only the publisher that had a protected right; but the new Statute focused on protecting the author rather than the publisher (Samuels 2000: Ch. 1). Copyright has subsequently become statutory through the Copyright Act 1911 (UK Copyright Service 2015). Today the relevant applicable UK law is the Copyright, Designs and Patents Act 1988 (hereinafter CDP Act), which will be examined in the following. Internationally, there have been a lot of attempts to harmonise the copyright law. The following will also examine a selection of these attempts; the Agreement on Trade-related Aspects of Intellectual Property Rights (hereinafter TRIPS) and The Berne Convention for the Protection of Literary and Artistic Works.

\subsubsection{Copyright, Design and Patents Act 1988}

The CDP Act is currently the main legislation that regulates copyright in the UK. The work needs to be qualified under the Act in order to be protected. The work will be qualified if e.g. the author of the work is a British citizen, resident in a country where the Act's provisions extend (a qualifying country) or is a body incorporated under British law. It can also be qualified if the work was first published in a qualifying country, cf. section 154 and 155.

\subsubsection{The Copyright Protection}

The Act protects original tangible works, cf. section 1 and 3This means that the creative effort has to be original and a work before it is protected. Being original in this context means that the work has to originate from the author and may not have been copied from another's work. There is also a minimum standard to the work. Even though this standard is low, it has to be acknowledged that there has to be some content to the work. The work also has to be tangible, which means that only a specific idea can be protected, while an expression of an idea cannot. The idea will become tangible through e.g. writing or recording. The last condition for protection is that there has to be a work. This Act specifically lists what can be considered to be a work. These are literary, dramatic, musical and artistic works, cf. section 3 and 4. In relation to music the protection of the music and the lyrics are separate; the music is protected as a musical work while the lyrics are protected as a literary work. Also secondary or

\footnotetext{
${ }^{3}$ The date on the statue shows that it was passed in March 1709, however, at that time the calendar year started on March 25 th. In 1752 the start of the calendar year was changed to January 1st, which means that the statute was actually passed in March 1710.
} 
derivative works can be protected, these are sound recordings (section 5A), films and broadcasts. A music work can therefore also include derivative protection for the recordings.

A copyright protection, which gives special rights, is given to the owner of the work, cf. section 2 . The first owner of this right is at the starting point the author of the work, cf. section 9 and 11. The protection for the musical and literary works lasts until 70 years after the death of the author, or 70 years after it was made available to the public, cf. section 12. The protection of the sound recording lasts 50 years from when it was made or published, cf. art $13 \mathrm{~A}$

The ownership of the copyright gives the right holder certain exclusive rights to copying the work, issuing copies to the public, perform show or play the work in public, broadcast the work and make adaptions to the work, cf. section 16. If any person other than the copyright holder does any of these things, which are restricted by the copyright, then they will infringe the copyright, cf. section 16(2), unless he has the necessary licence from the owner. It will be an infringement even if the act is only made in relation to parts of the copyright protected work, cf. section 16(3). In relation to music sampling, this means that the copyright will be infringed if a protected work is sampled without permission from the copyright owner.

Copyright is not only a moral right, cf. CDP part I, chapter IV, but it is also property, which the owner can control and dispose, this means that he can also transmit or assign this copyright, cf. section 90. Moral rights, which are the right to be identified and the right to object to derogatory treatment of the work, are not a property and they are therefore not assignable, cf. sections 77, 78, 80 and 94 . The copyright owner is allowed to both use and even give other permission to use his work. An owner can therefore allow others to sample his protected music. Often, artists will agree to a portion of the royalties in exchange for the use of the material (Poe 2006: 60).

\subsubsection{Copyright infringements}

If a copyright is infringed, then the owner can take action against the infringer. The copyright owner can seek relief by way of damages, injunctions and accounts, which would otherwise be available for other forms of property rights, cf. section 96 . The court, when assessing the infringement and the size of damages, has to take into account "the flagrance of the infringement" and the "benefits accruing to 
the defendant by reason of the infringement", cf. sections 97 (2)(a) and (b). The court has to award such damages, as the justice of the case requires.

This means that a musician, who wants to use a music sample from a protected work, needs to get permission from the author/copyright owner before using the sample unless it is more than 70 years since the death of the author. It has to be mentioned that a sound recording will not be protected by copyright to the extent that it is a copy of a previous sound recording, cf. section $5 \mathrm{~A}(2)$. This means that a sample will not be protected in a new work, but it will remain protected in its original form.

\subsubsection{Exceptions to Copyright Infringements}

Even though an artist is using copyright protected material, there can then in certain circumstances be exceptions to the infringement. There are two different exceptions to copyright; 'Fair dealing' and de minimis. Both of these exceptions are interpreted extremely narrowly by the courts, possibly too narrowly (Adeney 2012: 343).

The 'fair dealings' defence can be used as an exception to the copyright protection. If the use copyright protected works in a reasonable manner and for a fair dealing, cf. CPD Part I, Chapter III, such as the purposes of criticism, comment, news reporting, education etc. then a use will not infringe the copyright (Wilson 2002: 184) (Collie 2011: 2). When assessing whether it is 'fair dealings' or not, four non-exclusive factors have to be assessed. These factors are the purpose and character of the use, the nature of the use, the substantiality of the portion used and the impact on the potential market and value of the copyrighted work (Cambell 1994: 586-590).

The fair dealings defence will first be applied after the court has ruled that there has been an infringement. This means that the court additionally rules that the infringement will be allowed. And it is important to remember that this means that in theory this is a case of an allowed or permitted breach of law. It has been discussed whether the copyright laws or the interpretation of these should be changed, so that sampling could be included under these exceptions. This will be discussed further, later in this paper.

The second exception to copyright is the de minimis non curat lex exception (hereinafter the de minimis exception). The de minimis principle is a general norm in the common law system. It means 
that "the law does not take account of trifles" (Law 2015), in other words, the legal system should not deal with extremely minor offences to the law, and the defence can be used when the violation is so minimal that it cannot and should not result in any legal consequences. In relation to copyright and sampling, the principle means that the court should not deal with samples that fall below the required amount of substantial similarity (Wilson 2002: 185). If the de minimis exception is applied, then it technically means that there was no infringement of the law at all, which makes this exception even more important than the fair dealings exception.

The de minimis exception has been used often in relation to music sampling, and many artists have tried to argue in front of the court that they had only used a very short sample, and that it should therefore not be relevant to consider the possibility of copyright infringement.

The practical extent and implications of the de minimis exception will be discussed in the analysis section of this paper.

\subsubsection{International Harmonisation of the Copyright Rules}

Over the last few decades there has been a significant international harmonisation of the copyright rules. These rules have been created to ensure that copyright holders will also get protection internationally.

The first international copyright laws incorporation was the Berne Convention for the Protection of Literary and Artistic Works from 1886. The current revision of the Act is the Paris Act from 1971 with amendments in 1979. The Convention secures the protection of artists in the countries that has implemented it. The UK signed the Convention in 1886 and has been a party to it ever since. Currently 168 countries are contracting parties to the Convention (WIPO 2015(1)). The Berne Convention sets a protection of a minimum of 50 years post mortem auctoris (after the death of the author) (Adeney 2012:

The Berne Convention was followed by the Rome Convention in 1961, which expanded the protection to performing artists, radio etc. This Convention has today 92 contracting states including the UK. (WIPO 2015(2)) 
Both the Berne and the Rome Convention was created long before the new technological development, and it was therefore necessary to supplement them with additional legislation. This resulted in the creation of the Agreement on Trade-related Aspects of Intellectual Property Rights (the TRIPS Agreement) in 1994 along with the World Trade Organization (WTO).

These international conventions will not be mentioned further in this paper. However, the fair dealings and de minimis exceptions, which have been explained previously, will also apply in relation to the rules under all these international conventions. The following discussion of the de minimis exception will therefore also apply to the international copyright laws.

\subsection{Key Issues}

Music sampling is an art form that is still being used more and more, and it is therefore relevant to analyse the legal situation in relation to this genre, especially as method behind music sampling means that it is fundamentally built upon the use of someone else's copyright protected material. It has now been established that there are a number of applicable laws, however in relation to music sampling in

the UK, the primary legal resources have to be considered in relation to the CPD Act and its underlying exceptions.

The key issues that will be assessed in this paper will relate to these exceptions of copyright. Having determined the basis of the copyright and the basic rules, the paper will change its focus. Generally, copyright relates to the protection of rights, but this paper will try to assess the limitations to these rights and discuss when it is necessary to let these rights waive for the rights of the sampler. It will do this by analysing the current possibilities of applying the de minimis and the fair dealings exceptions to sampling cases. 


\subsection{Methodology}

This paper aims to address two different areas. Firstly, it is the aim to establish the current legal position regarding music sampling and copyright, secondly, to assess the effects of these current legal rules upon artists' views regarding using music sampling and their creativity. The methodology for this paper has therefore had to be considered in relation to these different parts individually. It will consequently be necessary to use different methods to these different sections, which means that the paper will therefore become a multi-method research. The overall research will be conducted as a critical social research paradigm, in the sense that the research will not only aim to understand, it is also meant to challenge the current positions and possibly help bring change to them.

In relation to the first area, the primary research will relate to the already existing data by the means of the law and the case law. This will therefore be based on a critical legal doctrine method. But it will simultaneously also use the basis legal "black letter" analysis, where the analysis is based upon the letter of the law (LawTeacher 2016). This black letter analysis will focus primarily upon the interpretation of the statutes and the case law. However the analysis will also take a more sociological approach, as it will include both qualitative and quantitative research methods in order to assess the impact of the law (LawTeacher 2016). It is the aim to gain empirical knowledge of this effect. In this research this empirical data have been collected through a survey. This survey will be used to interpreting the general perception of the law but it will also be used to get a perspective to the extent of the use of sampling today and the general view upon sampling among musicians. The survey will be explained in the next section. It is necessary to use this sociological analysis, as it will fill the gaps in the black letter analysis that cannot be used to understand the "law in action" (LawTeacher 2016).

In relation to the second area, the effects of the current legal rules, the same sociological approach will be used, since here the survey becomes be main method to analysing how musicians feel that the law affects them and their creativity.

\subsection{The Questionnaire}

The survey, which will be a quantitative research, was conducted to gain insight to the musicians' opinions of the law and its effect. The survey was created online through a survey website; Survey Monkey. 
My primary target market was the music performance students at University of the Highlands and Islands, as it would be easy to approach them at Perth College. It was the plan to have the survey emailed to all music performance students, however this was unfortunately not possible, so I was only able to get responses from a small group of students I was able to approach physically at the college. So I needed to expand the survey, both in order to get a greater number of respondents but also to expand the research to involve other groups of musicians. I therefore chose to also post the survey on social media. The survey was posted to my own person network as well as in all relevant British music groups on Facebook, such as London Musicians Network, Glasgow Musicians, Edinburgh and Lothians Music Scene and UK Musicians and Venues. The goal was to get at least 50 responses.

A quantitative research is an empirical research where the data is collected and analysed in numbers (Blaxter 2006: 64). This form of research is supposed to look at a larger picture and a more widespread. The qualitative research on the other hand aims to go into more detail or depth, it is said to be a research that it not in the form of numbers (Blaxter 2006: 64).

The analysis of the data will primarily focus on the quantitative aspect of the questionnaire, and it will focus on the descriptive statics analysis. The data will be used as nominal data (Blaxter 2006: 217). The main focus on the quantitative data has been chosen, as it becomes easier to analyse more general views upon the subject, and it will therefore be easier to place the individual responses into a larger picture. Using quantitative data allows the paper to draw clearer lines between the survey respondents and the general view among all musicians, as it will be assumed that the respondents can be seen as a small sample of the average musicians. The survey can therefore be used for a sample analysis (Qualtrics 2013). The qualitative data from the survey will then additionally be used to gain a deeper knowledge of the motivations behind individual responses.

\subsection{The Results}

The survey had 66 respondents; $60 \%$ men and $40 \%$ women. $56 \%$ of the respondents were between 18-24 years, while $38 \%$ were older.

Question 3 showed that $48 \%$ had used music sampling, question 4 and 5 showed that $86 \%$ think that music sampling is acceptable, while $80 \%$ would feel ok about having their own music sampled. The 
answers to question 6 varied a lot, however $23 \%$ said that there should never be a limit to the length music sampling. Question 7 showed that $53 \%$ thought that there were no disadvantages to having limitations to music sampling. Question 8 showed that only $6 \%$ thought that music sampling should be illegal, while question 9 showed that $53 \%$ thought it should be completely legal. Finally, question 10 showed that $52 \%$ thought that limiting sampling could also limit creativity.

The quantitative survey results will be used in the analysis section to examine or underline the current understandings and views upon music sampling. While the qualitative results will be interpreted and used to get a deeper understand upon the background of the quantitative survey responses.

\subsection{Discussion / Analysis / Case Studies}

The following discussion will examine the possibility for applying the previously mentioned exceptions to copyright upon music sampling. First the fair dealings exception will be considered and secondly the de minimis exception will be examined. The last part of this section will analyse the effect the current legal situation has upon creativity.

But before dealing with these issues, it is necessary to consider the purpose and reasons behind copyright and the exceptions to it, as this will provide a necessary knowledge, which has to be applied when interpreting the rationales in the law and the courts' decisions in the analysis.

In addressing and analysing these regarding music sampling and copyright, it is necessary to simultaneously also analyse the American position and case law. Mainly because it can be an important help in the interpretation of the UK situation, as there has been a greater extent of court cases in the US. Additionally, the US and UK statues to a great extent mirrors each other, and they are additionally based upon the same legal theories found in all common law countries. It especially becomes important to look towards the American legal stand and their courts' decisions, as there currently has still not been a single verdict regarding sampling and copyright in the courts in the UK. There has been several cases that has been started up as court cases, but which have ended up being settled outside court, e.g. when The Rolling Stones sued The Verve for breaching a licensing contract, when they allegedly used a longer sample than allowed in their track "Bitter Sweet Symphony". The fact that the artists and record labels in the UK keep away from the courts and settle their disputes themselves, shows that it is unclear what position the UK courts might take in a case. The parties will simply not risk taking their 
disputes to court, as they cannot predict the outcome and it will most likely be cheaper to settle the cases themselves. This also clearly shows that it is necessary to have the state of law clarified.

The next part will therefore also consider the American concept of "fair use", which is almost equivalent to the UK concept of fair dealings. But it will also consider the differences between the two concepts

\subsection{The Considerations Behind Copyright and its Exceptions}

In order to analyse the law and understand the reasoning behind the outcomes of cases in the courts, it is important to understand the purpose of copyright and the reasons behind the current law. In the US and in the UK the copyright protection is mainly designed to protect the economic interest of the copyright holders. The statutes have been created around the objective to balance these rights of the copyright holder with a range of other rights, interests and freedoms.

The exceptions regarded as fair dealings must be regarded as being mainly based upon social objectives; such as education, libraries and archives. But most important is the freedom of expression, which should be protected, but only as far as it does not hurt the copyright holder. This is the reason for the possibility of using copyright protected material for criticism and reviews.

All these reasons have to be considered and weighed against each other by the courts in all copyright cases. So when the courts have to consider whether the exceptions should apply, then the need to consider whether in the specific situation it is necessary to determine that the considerations for the freedom of expression etc. is deemed more important.

\subsubsection{The Fair Dealings Exception}

Currently the fair dealings exceptions in the CPD Act explicitly state what can be considered an exception to copyright. However, it has been seen in a few American cases that artists were attempting to get their sampling considered as a fair use. Unfortunately, as the statutes are currently formed, this exception does not seem to be able to be extended to include samplings, unless the sampling is used in relation to one of the exceptions, which most likely will be for the creation of a parody. In the American case of Campbell v. Acuff-Rose Music, Inc. from 1994, Roy Orbison's “Oh, Pretty Woman” was sampled by the rap group 2 Live Crew. 
The Supreme Court held that the use could be rendered as fair use, as the song was a parody under $\S 107$ of the Copyright Act of 1976. This was the first case where it was ever settled that a parody was a protected form of speech within the scope of $\S 107$. In this court case, the court began the case by describing the need for the balance between protecting copyright while still allowing others to build on it. It was also described how it has to be analysed whether a use is fair use, then the court need to..."look to the nature and objects of the selections made, the quantity and value of the materials used, and the degree in which the use may prejudice the sale, or diminish the profits, or supersede the objects, of the original work."

The Federal Court held that the use could not be considered fair, due to the commercial nature, whereas the heart of the original work had been sampled to become the heart of the new work. However, the Supreme Court in the end held that the 2 Live Crew's parody should be considered a fair use under $\S$ 107 , and that a commercial nature did not necessarily mean that a use had to be unfair.

$\S 107$ of the Copyright Act does not itself directly list that a parody can be fair use, however it states the same fair use exceptions as the CPD Act, such as education, criticism etc. It can therefore be questioned whether a parody would also be included in the interpretation of the fair dealings exceptions under CPD Part I, Chapter III. It is most likely that the UK courts would interpret the exceptions in the same manner. However, one factor could possibly cause the courts to have a different perspective is that fact that the CPD Act states in greater detail what should be considered a fair dealing, while $\S 107$ merely states that acts "such as criticism, comment, ...". The wording "such as" clearly shows that the list is not exhaustive, whereas the list in the CPD Act could be seen as exhaustive due to the extent and detail in CPD Part I, Chapter III.

In 2006 a Growers Review (Grower 2006), an independent review, of the CPD Act recommended that the fair dealings section of the Act should be changed so that it could include an exception for transformative use (sampling), however it was not possible due to the "exceptions set out as permitted in the Information Society Directive", and the review board as a start could only suggest that the directive should be amended. However, the board also emphasised the importance of parodies and the value that they can create. It mentions as an example of the possible value, Weird Al Yankovic and his parody songs, for which he received 25 gold and platinum albums and two Grammys. The boards $12^{\text {th }}$ 
recommendation was therefore to "create an exception to copyright for the purposes of caricature, parody or pastiche by 2008 ". This amendment has still not been created.

The recommendation also shows that it is the general view that the current exceptions in the CPD Act should be considered exhaustive, and at this current state a parody will not be considered a fair dealing in the UK courts.

It has in no other circumstances been possible to apply the fair dealings/fair use exception to sampling, which presumably must mean that the sampling can never be considered fair dealings in the UK courts, where as in the US courts sampling cannot be considered a fair dealing unless it is used in a parody. Hopefully, in the future the recommendations of the Grower Review will be considered and added to the CPD Act, in so making it a fair dealing to use sampling both for parodies and any other form.

If the courts were ever to consider that a parody or something else falls under a fair dealings exception, then it itself does not necessarily mean that there is not an infringement. In these cases the courts have to consider whether the specific dealing is fair. This test includes interpreting the nature of the work, how the work was obtained, the amount taken, motives, commercial benefits, etc. Artists therefore have to remember that a dealing, which falls under a fair dealings exception, can still be considered unfair and therefore lead to conviction.

\subsubsection{The 'de Minimis non Curat lex' Exception}

The de minimis principle is a well-known concept across all legal systems. It is a principle that is needed to protect the courts from spending unnecessary time and money on trivial matters. It is not a principle that necessarily has to be mentioned explicitly in the law, as it will always apply indirectly. However the CPD Act section 16(3) is based upon this principle. This section states that if the use of a protected material, does not relate to a substantial part of the material, then an act, even if it is not a fair dealing, will not constitute an infringement. This does, however, open up another question - what will qualify as substantial? And is it a qualitative or quantitative criterion? This following section will try to analyse what the courts in the UK would possibly consider to be substantial. The section will analyse how the American courts have used the de minimis exception in relation to music as well as considering what the British courts and scholar point of view might be. 


\subsubsection{The Basis of the 'de Minimis Exception'}

The basis of the de minimis exception in UK copyright is found in section 16(3), which reads:

"References in this Part to the doing of an act restricted by the copyright in a work are to the doing of it--(a) in relation to the work as a whole, or any substantial part of it ..."

According to this provision the core of a copyright case will concern whether the sample constitutes a substantial part of the protected work. Only if it is so, then the act will be infringing. The question then relates to how long a sampling can be before it constitutes a substantial part.

In the questionnaire it was asked how long the respondents thought should be allowed. It is clear from the answer that there is a mixed view upon this. Only a small majority of people $(17 \%)$, who chose a time length, thought that there should be a limit of 10 seconds. While $7 \%$ thought that all sampling should be illegal, and $23 \%$ thought that there should never be a limit. These answers do not only show that there is a split view upon sampling, but it indirectly also shows that there is a great uncertainty of what it legal. If the artists knew what was legal, then they would most likely unconsciously pick the legal amount.

It has been said throughout the music industry that there was an unwritten 3-second rule (McKenna 2000). However even though the music industry might find 3 seconds appropriate, the courts might not necessarily agree.

It will probably be impossible to determine a specific length of a legal sample, as it has to be considered what has been sampled, whether it is the heart of the original work or if it is a trivial part of the original work. It also has to be considered how the sample is used; if it is the primary part of the new track or if it is a minor part of it. So the courts would have to apply the same test to the sample as they would have to in relation to the fair use. In general this test can be seen as a proportionality test, which is a test the courts should consider in every single case regardless of subject. This has also been seen in most recent sampling court cases, cf. Tuff ' $\mathrm{N}$ ' Rumble Management Inc. v. Profile Records Inc.

Despite the unlikeliness of determining a legal threshold for sampling, the following will examine how the exception has been used previously within US courts. 


\subsubsection{Former Use of the 'de Minimis Exception'}

One of the first cases to ever determine that the de minimis principle could be applied in copyright law, was a case from 1909, in the case the Judge stated that: "Even where there is some copying, that fact is not conclusive of infringement. Some copying is permitted. It must be shown that it has been done to an unfair extent" (West Publishing Co. v Edward Thompson Co.)

One of the leading cases on the de minimis principle in copyright is Fisher v Dees. In this case the court established that there could only be an infringement when the average audience would discover a similarity. The case was one of the first to establish the link between the de minimis principle and the substantial similarity demand. These cases also determine that there is a clear possibility to apply the de minimis in copyright cases. However, the question arises whether this also includes cases regarding music sampling or derivative works. The following will analyse a number of US cases, whose issue was the link between music sampling and the de minimis exception. As sampling affects both the rights in relation to the composition and the recording, then these and their relation to the de minimis will be analysed separately in the following.

\subsubsection{In Relation to the Composition Rights}

The possibility to use the de minimis exception in relation to composition rights was confirmed in the case of Newton v Diamond. In this case the Central District Court of California held that the Beastie Boys' sampling of a three-note sequence and one background note from Newton's song "Pass the Mic", was neither a qualitative or quantitative substantial, which meant that the sample was de minimis and could therefore not amount to an infringement.

In the case the Beastie Boys had managed to get license for the sound recording through Newton's record label, however they had not been able to obtain license for the underlying composition. Newton therefore sued Beastie Boys for having infringed his copyright by copying a 6 second section of "Choir". The Beastie Boyes had only obtained license for the recording, but had been unable to get license for the underlying composition. The court therefore only had to consider infringement of the composition. The court here considered whether the sample was of a particular qualitative or quantitative quality, which could cause an infringement. However the court concluded that the underlying composition, $\mathrm{C}-\mathrm{D}$ flat $-\mathrm{C}$, sung over a background $\mathrm{C}$ note, was of no significance and could therefore not be protected. 
This case could possibly show that using any smaller segment of a composition will most likely be de minimis, as the notes in themselves cannot be considered unique and significant - whereas the significance is established in the performance and the recording.

\subsubsection{In Relation to Recording Rights}

A recent case of the US Court of Appeals for the Sixth Circuit ruled regarding the possibility to use the de minimis defence in relation to music sampling and recording rights. The case, Bridgeport Music, Inc. v. Dimension Films raised the issue of using the de minimis defence. The case addressed N.W.A's song 100 Miles and Running, in which there was a sample from George Clinton and the Funkadelic's song Get Off Your Ass and Jam. The sample was a two second guitar chord, which had been lowered in pitch and looped five times in the new song. The defendants did not contest the use of sampling, but they tried to argue that the sample was de minimis and should therefore not be considered to be an infringement of Bridgeport Music rights due to the de minimis exception. The Federal Court ruled that there was no infringement, however the appeal court overturned this ruling. The appeal court started their ruling by saying, "Get a license or do not sample. We do not see this as stifling creativity in any significant way", which clearly showed the courts view upon sampling. Furthermore, the court concluded that "even when a small part of a sound recording is sampled, the part taken is something of value", and it would therefore not matter how much was sampled. Ultimately the court concluded that music sampling would regardless of its length always infringe copyright. The same attitude was adopted by the court in the case of Grand Upright v Warner, which is known for the quote "Thou shall not steal", as well as the court refusing to even consider the de minimis exception.

In Bridgeport Music v. Dimension Films, the court argued that it is following the general view in the music industry, and that it would only primarily be musicians within the rap/hip-hop music genre that would disagree with this point of view and see the ruling as stifling creativity. However, the survey conducted in relation to this paper clearly showed that there generally is a greater positive view upon sampling as being a good thing.

This case however will only be binding for the Sixth Circuit in America (Kentucky, Michigan, Ohio and Tennessee), and hopefully other courts will not take the same position. And the case Grand Upright v. Warner was only from a district court can could therefore possibly be overruled by the court of 
appeals, and it is therefore not binding for any district or higher courts. And it must be considered that in some circumstances the de minimis exception can apply. The exception is clearly stated in the CPD Act, so the only question relates to the extent of the exception, and whether CPD Act s 16(3) should be seen as a qualitative or quantitative test of the sampling. The US ruling mentioned that the current copyright law in America did not have such as wording.

Which meant that the court had had taken a literal approach in regards to the interpretation of the law, which meant that they had had applied the wording directly in this case, and thereby disregarded any possibility for underlying principles. Unfortunately, rulings like this might possibly harm the music industry in the longer term, if this ruling becomes precedence for future rulings, as it completely undermines a well-known and recognised music genre. However, it has been seen that other courts have been more willing to accept the de minimis defence, e.g. in a case from 2014, TufAmerica, Inc. v. Warner, a sample of the word "oh", which was used more than 40 times in the new work, was considered to be de minimis. This ruling was by the same court that in the case of Grand Upright v. Warner had stated that the de minimis exception would never apply to sampling.

The possible extent of the de minimis exception must depend on a specific test of whether the sample amounts to an unlawful appropriation, by being substantially similar, cf. Marlon Williams v. Calvin Broadus, Newton v. Diamond etc. There is therefore a clear relationship between the de minimis consideration and the substantial similarity test.

\subsubsection{The Substantial Similarity Test}

In order to determine whether a sample will be lawful or not it is necessary to apply a similarity test. By applying this test to the specific case, it will be possible to determine the specific threshold for lawful sampling. The test has to be used ad hoc, and it might therefore not be possible to determine a general threshold for all sampling. However, it will be possible to establish some general rules and guidelines. In the following it will be attempted to determine what the courts consider to constitute an infringing similarity.

As sampling means to copy a specific piece of existing music and use it in a new work, then it will generally be similar or there will at least be a high degree of similarity. In reality, unless the sample has been altered or digitally manipulated, then it will be identical to the original work. In general copyright 
law is an area that is often dealing with a high degree of similarity, and it has therefore been established that if "the similarity is only as to nonessential matters, then a finding of no substantial similarity should result" (Nimmer) (Newton v. Diamond) despite the sample being completely similar to the original work. This form of similarity, where a work has been copied directly, has by the courts been described as a fragmented literal similarity, which does not necessarily cause an infringement. In these cases where there will be a high degree of similarity or a fragmented literal similarity, it is necessary to consider whether the similarity is trivial or if it has substantial essence.

One of the first US cases that tried to establish the substantial similarity test was "Jarvis v. A \& M Records" from the District Court of New Jersey in 1993. In this case, where a bridge section and a keyboard riff had been sampled, the court argued how the substantially similarity test should be considered. Firstly the court concluded that the test would always be an ad hoc test, which then subsequently will mean that there is no general answer to what can be considered substantial similarity. They also conclude that the test generally has been considered to be a test of whether an ordinary lay (a person, who does not have professional or specialised knowledge of the subject) person would consider the two works similar (see also Bridgeport Music, Inc. v. UMG Recordings, Inc.). The court dismiss the idea that a sample could only infringe a work within it's own genre, meaning that e.g. a sample in a rap song could never infringe a pop song. The court clearly states that this is not the case, and the test has to be conducted without regards to the musical genre. This has also been seen in other cases where the court concluded that there were infringements, even when the two works were completely different and where they reached completely different markets (Grand Upright v. Warner).

Lastly, the court defends the general quality/quantity test by explaining its significance by explaining how the value of a work can be diminished even if a small (but qualitative important) part of the work has been copied.

It therefore seems as though the test should always include both a qualitative and quantitative aspect, in so that the similarity and thereby infringement can either occur if the sample has a certain length (quantitative) or if the sample comes from the heart or an important part of the original work (qualitative). In so that it is the quantitative and qualitative significance of the sample that has to be considered in relation to the original work (Newton v. Diamond, Marlon Williams v. Calvin Broadus). And here is it not relevant to consider how substantial a part of the sample is in the new work. This reflects the general infringement test, which has been known since the creation of copyright. In 1841 
Justice Story states the question relates to whether "so much is taken... that the value of the original is sensibly diminished, or the labors of the original author are substantially to an injurious extent appropriated by another" (Folsom v. Marsh).

By determining the substantial similarity in relation the significance in the original work will protect against insensible use, which could otherwise just be concealed among non-infringing material in the new work. The test will therefore have to consider both the qualitative and quantitative aspect of the used sample. It is likely that the qualitative aspect of the test will be of greatest importance to the substantial similarity test (Bridgeport Music, Inc. v. UMG Recordings). As the length of the sample becomes unimportant if the sample only relates to an unqualified and unsubstantial part of the original work.

\subsubsection{The Extent of the 'de Minimis Exception' in Relation to Music Sampling}

Unfortunately, it will not be possible to set some more clear rules for the allowed extent of sampling, as the courts have to consider each case individually. It has been considered among the music industry that there was an assumption that there was a 3-second rule (McKenna 2000), meaning that any sampling less than 3 second would be allowed. However, the courts (at least in America) do not agree with this perception, and have often ruled shorter samples to constitute infringements. Even the American courts have concluded that it is necessary to establish a bright-line rule (Bridgeport Music v. Dimension Films), however such a rule can only be established by the courts or through legislation. And the legal situation for sampling will, until then, be unclear.

If a musician were to use sampling, then it has to be recommended that he obtain the necessary license or at least limit the sampling to an insignificant and short part of the original work if he wants it to be allowed under the de minimis exception. This will of course limit the possibility for sampling dramatically, and this does not reflect the general views among musicians. The survey showed that 86 $\%$ of the respondents thought that sampling was acceptable (question 4), as long as there was some sort of permission granted. And only $8 \%$ thought that sampling should never be permitted (question 6 ). 80 $\%$ would not mind if their own music was sampled, which clearly shows the more open-mindedness regarding sampling among musicians. The use of sampling is still expanding, through cheaper and easier sampling software, and it makes it more important for the courts to establish these bright-line rules so that musicians will know how to act in relation to sampling. 


\subsubsection{In Relation to Looping}

The next question that can occur after establishing what can be interpreted as an accepted sample within the de minimis exception is; if an allowed sample is looped - will the de minimis exception still apply?

The substantiality test clearly shows how it will not have any significance whether the sample is looped or not, as the significance of the sample has be considered in relation to the original work and not the new work. In theory it should therefore be concluded that as long as the sample is of an insignificant quality or quantity of the original work, then it does not matter how much it has been used in the new work.

This has also been seen in some court cases, e.g. in Newton v. Diamond, where the court did not even consider the relevance of the sample having been looped so that it appeared more than 40 times in the new work. The court here clearly stated how the sample should be considered in the light of the original work.

\subsection{Music Sampling and Creativity}

It has so far been established that there is generally a reluctance by the courts to acknowledge the importance of allowing music sampling, and they generally seem to take the side of the plaintiff, leaving sampling musicians with very little room for working within their genre. But what effect does this have on the sampling musicians and musicians in general. The following will consider how creativity can be destroyed if musicians are not given the complete freedom to explore their imagination.

\subsubsection{Application and Interpretation of Copyrights Rules, Limiting Effects on Creativity}

The objectives of the copyright law so to ensure that there would be incentives for artists to use their creativity to create new works, in so that the creators could enjoy the fruits of their creations (Bridgeport Music v. Dimension Films). By instantly giving the artist the rights to his work, the artist would be financially protected in relation to the work. The law was therefore meant to become a form of protection, which should ensure that creativity could flourish. The problem, which is now arising, is 
that this law is now starting to limit creativity, and thereby going against its objectives. The current copyright law seems to be putting up barriers for the development of the creativity, and the courts lack the insight to and understanding behind sampling. It has been seen that courts have a wrong perception of the purposes for using sampling.

Courts often see sampling as a method for saving production costs, and they therefore do not see the creative aspect of sampling (Bridgeport Music v. Dimension Films). In relation to sampling both the law and the courts seems to impose to high demands, which causes a limitation of creativity within this art form. Do the artists themselves see this hurdles, when they work with their music? The conducted survey aimed to assess what point of view that musicians had upon sampling, and especially whether they felt that copyright law limited their creativity. Despite only a small majority of $53 \%$ the respondents in the survey stated that they believed that limiting sampling could have negative effects on creativity (question 10), when looking in to their individual responses, it was clear to see that the majority in fact did believe that these limitations could have a undesirable effect.

Here is a selection of some of the comments from the respondents that believed that limiting sampling could also limit creativity:

- Sampling is an art form in itself. Some sounds are unique and we have an idea we would like to try having felt inspired by a particular recording. To say that an artist must definitely never use sampling would therefore limit the building blocks that an artist is allowed to use to create their art. This can therefore lead to limiting the artist's creativity.

- Because it's a vogue form of expression in our day and age and limiting it's use is akin to stifling creativity in a new wave of artists

- Creativity should never be stopped, some people are incredible artists and if they use a few seconds of your work but give you some credit, then I don't see the problem

- Sampling can add another facet to a musician's repertoire, the more in the armoury, the more creative they can allow themselves to be. 
- I guess it can become very limiting for some artists, who work best by developing already existing creative material

Some respondents did however believe that sampling should just seen as an additional tool, which should not completely rely on.

But if the copyright law and limitations to sampling are seen as having a limiting effect on creativity, what can be done to circumvent this limitation? The courts have believed that the music industry itself can ensure this circumvention by establishing fixed licensing fees and controlling that these are "keep it within bounds" (Bridgeport Music v. Dimension Films). But even if there will be more focus on creating larger licensing houses etc. then having to obtain a license can make the process of sampling long and hard, especially if the sampler has used more samples from more than one original work. It is therefore more important to have established this bright-line rule for sampling, so musicians can use the art form within its clear limitations without fearing legal actions.

\subsection{Conclusion and Recommendations}

\subsection{Conclusion}

The current legal situation regarding music sampling in the UK is almost completely unknown, as neither the courts or the law have specifically considered the issue. The fact that no music sampling cases have been settled by the courts makes it impossible to predict in what way a court would decided in a given case.

It is clear that music sampling is an issue, which has not been given the necessary attention by the legislators. Even though independent reviews have recommended that the CPD Act should be modified to include music sampling as an exception under the fair dealings section. However, no such changes have been made and the legislators have clearly ignored the subject, which is why it is still unclear whether music sampling to a certain extent can be legally accepted.

In this paper it was attempted to settle this legal uncertainty by discovering whether any exceptions under the CPD Act could be applied in an situation relation to music sampling. 
Firstly, it was showed that the fair dealings exceptions under the CPD Act could not include music sampling. In America it has been seen that the almost similar "fair use" exceptions under the Copyright Act may be used in some particular circumstances. Especially when the sampling was used for the purposes of creating a parody, then this would be allowed as fair use. However, this same position will not be seen in the UK. The fair dealings exceptions under the CPD Act. have been interpreted narrowly and the list is exhaustive. This means that the only allowed exceptions are the ones directly mentioned in the Act. These are for the purposes of education, criticism, reviews etc. All of which music sampling cannot fall under. It can therefore be concluded, that the fair dealings exceptions under the current provisions in CPD Act can in no circumstances be extended to include music sampling.

Secondly, the paper aimed to discover whether the de minimis exception could be applied to music sampling. The paper showed how there had been different approaches to the subject by the different US courts. Some districts had an approach where any use of sampling was seen as illegal, while others took a more relaxed attitude and allowed sampling in some specific cases. Generally it could be established that the de minimis exception could be applied to music sampling, however, it was not possible to establish a particular threshold for legal music sampling. In order to establish whether a sampling is legal, the substantial similarity test had to be applied, and this means that it will be very individual what can be considered as an acceptable sample length. Therefore, the de minimis exception could be applied in situations where the sample was insubstantial or lacked a certain degree of similarity.

Thirdly, the paper looked at the relationship between the current legal situation and the effects on musician's creativity. It was showed how musicians felt that the limitations to music sampling would also limit their creativity. It simultaneously also showed how the majority of the questioned musicians thought that it was important not the limit music sampling, or that it should at least be easier to use sampling as a creative method.

It is clear that the current copyright laws in the UK have not followed the technological developments. It is necessary to ensure that the legislation reflects these changes through modifications of the current CPD Act or interpretation of it.

So far music sampling has not been given the appropriate acknowledgement as a specific art form. It is crucial that music sampling is given the necessary approval by courts and legislation. As a general starting point it is only fair that it is necessary that sampler need to have the specific approval and 
license from the original copyright owner. However, in some circumstances sampling does not have a negative effect on the original work, this can e.g. be due to the extent or the specific sort of use of the sample, and in these situations it is necessary to allow sampling. In these situations, it is necessary to either let the fair dealings include music sampling or let the de minimis apply on insubstantial use of samples.

\subsection{Recommendations for Further Studies}

There has been a general approach among the European Union member states to establish more harmonised legal systems. This has also been seen in regards to copyright law, and it would therefore be relevant to consider and analyse the legal situation in other EU countries, despite most of these are based upon civil law traditions. Especially in Germany, there have been a lot of focus upon the legality of music sampling, and this would be a good starting point for a further study of the subject. 


\subsection{Bibliography, Case List and Glossary}

\subsection{References}

Adeney, E., 2012, Sampling and Remix Dilemma: What Is the Role of Moral Rights in the Encouragement and Regulation of Derivative Creativity, The, Deakin L. Rev., 17, p. 335.

Baroni, M.L., 1993, Pirate's Palette: The Dilemmas of Digital Sound Sampling and a Proposed Compulsory License Solution, A, U. Miami Ent. \& Sports L. Rev., 11, p. 65.

Blackowicz, J.U., 2001, RIAA v. napster: Defining copyright for the Twenty-First century, BUJ Sci. \& Tech. L., 7, p. 182.

Blaxter, Loraine, et. al, 2006, How to Research, third edition, Open University Press.

Bloch, D.S., 1997, Give the Drummer Some-On the Need for Enhanced Protection of Drum Beats, U. Miami Ent. \& Sports L. Rev., 14, p. 187.

Chanan, M., 1995, Repeated takes: A short history of recording and its effects on music, Verso.

Collie, C. \& Gorman, E., 2011, Digital Sampling of Music and Copyrights: Is It Infringement, Fair Use, or Should We Just Flip A Coin?

Collins, Wallace, 2015, Before You Sample That Track, Please Read This..., Digital Music News Cornish, G.P., 2004, Copyright: interpreting the law for libraries, archives and information services, Facet.

Cornish, W.R., Llewelyn, D. \& Aplin, T.F., 2013, Intellectual property: patents, copyright, trade marks and allied rights.

De la Torre, C.R., 2004, Digital Music Sampling and Copyright Law: Can the Interests of Copyright Owners and Sampling Artists be Reconciled, Vand. J. Ent. L. \& Prac., 7, p. 401.

Flint, M.F., 2014, A user's guide to copyright, Butterworth-Heinemann.

Frith, S. \& Marshall, L., 2004, Making sense of copyright, Music and copyright, pp. 1-18.

Granstrand, O., 1999, The economics and management of intellectual property towards intellectual capitalism, External organization.

Greenfield, S. \& Osborn, G., 2004, Copyright law and power in the music industry, Music and Copyright, p. 89. 
Grower (2006), Growers Review of Intellectual Property, December 2006, HM Treasury, accessed $7^{\text {th }}$ April 2016,

$<$ https://www.gov.uk/government/uploads/system/uploads/attachment_data/file/228849/0118404830.p df $>$.

Halloran, M.E., 2001, Musician's business and legal guide, Pearson PTR.

Harris, F., Pedley, P., Wall, R.A. \& Norman, S., 2004, Copyright made easier, Routledge.

Harvard Law Review Association, H.L.R., 1992, A New Spin on Music Sampling: A Case for Fair Pay, Harvard Law Review, 105(3), pp. 726-44.

Herzfeld, Oliver, 2012, The Beastie Boys' Sampling And Copyright Law, Forbes.

Hodgkinson, Tim, 1986, An Interviw with Pierre Schaeffer - pioneer of Musique Concréte, 2. May, ReR Quaterly magazing, volume 2, number 1.

Hollander, D.B., 2013, Why Can't We Be Friends-How Congress Can Work with the Private Sector to Solve the Digital Sampling Conundrum, Va. JL \& Tech., 18, p. 229.

Howell, A., Sample This! A Ninth Circuit Decision Seems to be in Harmony with the Sixth Circuit's Bright-Line Rule on what Constitutes Infringement in Digital Sampling, LA LAW., 28, pp. 24-6.

Landau, M.B., 2015, Are the Courts Singing a Different Tune When It Comes to Music?: What Ever Happened to Fair Use in Music Sampling Cases? IP Theory, 5(1).

Law, Jonathan. A Dictionary of Law. Oxford University Press, 2015.

LawTeacher (2016), Writing a Law Dissertation Methodology, accessed 15. April 16, $<$ http://www.lawteacher.net/law-help/dissertation/writing-law-dissertation-methodology.php>.

Lindenbaum, John, 1999, Music Sampling and Copyright Law.

Lubin, A.K., 2014, Digital Music Sampling and Modern Music: The Need for the 'De Minimis' Exception, Law Student Scholarship Paper 519.

McKenna, Tyrone, 2000, Where Digital Music Technology and Law Collide - Contemporary Issues of Digital Sampling, Appropriation and Copyright Law, JILT 17.

McLeod, K., 2001, Owning culture [microform]: authorship, ownership, and intellectual property law, Peter Lang Publishers.

Nimmer, Melville B., 1997, Nimmer on Copyright (vol. 4), Matthew Bender, New York. 
Olwan, R.M., 2013, Intellectual property and development: theory and practice, Springer, Berlin; New York.

Passman, D.S., 2012, All you need to know about the music business, Simon and Schuster.

Pedley, P., 2007, Digital copyright, Facet Pub, London.

Pelletier, J.S., 2011, Sampling the Circuits: The Case for a New Comprehensive Scheme for Determining Copyright Infringement as a Result of Music Sampling, Wash. UL Rev., 89, p. 1161.

Poe, Randy. The New Songwriter's Guide to Music Publishing: Everything You Need to Know to Make the Best Publishing Deals for Your Songs. Cincinnati, Ohio: Writer's Digest Books, 200

Posner, R.A., 2005, Intellectual property: The law and economics approach, Journal of Economic Perspectives, pp. 57-73.

Qualtrics, 2013, An Intro to Sampling, accessed 15 April 16, <https://www.qualtrics.com/wpcontent/uploads/2013/05/Sampling.pdf $>$.

Samuels, 2000, The illustrated story of copyright, Samuels ed. Thomas Dunne Books/St. Martin's Press, New York.

Schuster, W. Michael, 2013, Fair Use, Girl Talk, and Digital Sampling: An Empirical Study of Music Sampling's Effect on the Market for Copyrighted Works, Oklahomo Law Review, 67, 443

Self, H., 2001, Digital Sampling: A Cultural Perspective, UCLA Ent. L. Rev., 9, p. 347.

Smart, U., 2013, Music: The Business. The Essential Guide to the Law and the Deals, 5th End by Ann Harrison, (Chatham, UK: Virgin Books, Random House, 2011), ISBN: 978-0-7535-3958-3, Entertainment Law Review, 24(1), pp. 33-4.

Suppapola, M., 2005, Confusion in the Digital Age: Why the De Minimis Use Test Should Be Applied to Digital Samples of Copyrighted Sound Recordings, Tex. Intell. Prop. LJ, 14, p. 93.

Théberge, P., 2004, Technology, creative practice and copyright, Music and Copyright, 2, pp. 139-56.

The UK Copyright Service, 2015, UK Copyright Law: A Summary, $<$ https://www.copyrightservice.co.uk/copyright/uk_law_summary>

Walterscheid, E.C., 1999, Defining the patent and copyright term: term limits and the intellectual property clause, J. Intell. Prop. L., 7, p. 315.

Who Sampled, 2015, About, <http://www.whosampled.com/about/>.

Wilson, S.R., 2002, Music sampling lawsuits: Does looping music samples defeat the de minimis defense, J. hiGh TeCh. 1., 1, p. 179. 
WIPO, 2015 (1), Contracting Parties > Berne Convention,

$<$ http://www.wipo.int/treaties/en/ShowResults.jsp?treaty_id=15>

WIPO, 2015 (2), Contracting Parties > Rome Convention,

$<$ http://www.wipo.int/treaties/en/ShowResults.jsp?treaty_id=17>

Wixen, R.D., 2009, The plain and simple guide to music publishing, Hal Leonard Corporation.

Wolf, T.P., 2009, Toward a 'New School Licensing Regime for Digital Sampling: Disclosure, Coding, and Click-Through, Stanford Technology Law Review, Forthcoming.

\subsection{Case List}

Bridgeport Music, Inc. v. Dimension Films, et. al. 410 F. 3d 792 (6 ${ }^{\text {tt }}$ Cir. 2005)

Bridgeport Music, Inc. v. UMG Recordings, Inc 585 F. $3 d 267$ ( $6^{\text {th }}$ Cir 2009)

Campbell v. Acuff-Rose Music, Inc. 510 U.S. 569 (1994)

Fisher v. Dees 794 F. 2d $432\left(9^{\text {th }}\right.$ Cir. 1986)

Folsom v. Marsh, 9. F. Cas. 342 (C.C.D. Mass. 1841)

Grand Upright, Ltd. v. Warner Bros. Records Inc. 780 F. Supp. 182 (S.D.N.Y. 1991)

Jarvis v. A \& M Records 827 F. Supp. 282 (D.N.J. 1993)

Marlon Williams v. Calvin Broadus No. 99 Civ. 10957 (MBM), 2001 WL 984714 (S.D.N.Y. Aug. 27, 2001)

Newton v Diamond 349 F. 3d 591 ( $9^{\text {th }}$ Cir. 2003)

TufAmerica, Inc. v. Warner Bros. Music Corp., et al. 67 F. Supp. 3d 590 (S.D.N.Y. 2014)

Tuff 'N' Rumble Management v. Profile Records 42 U.S.P.Q. 2d 1398 (S.D.N.Y. 1997)

West Publishing Co. v. Edward Thompson Co. 169 F. 833 (C.C.E.D.N.Y. 1909) Modified 176 F. 833 (2d Cir. 1910)

\subsection{Legislation}

Copyright Act of 1976

Copyright, Designs and Patents Act 1988

Agreement on Trade-related Aspects of Intellectual Property Rights 1994

The Berne Convention for the Protection of Literary and Artistic Works 1886, amended 1979 


\subsection{Glossary}

\section{CPD Act:}

De minimis:

New work:

Original/existing work:
Copyright, Designs and Patents Act 1988

(De minimis Non Curat Lex) The principle meaning "the law does not concert itself with trifles".

The new work that the sample was used in

The original work from which the sample was taken 